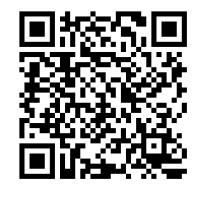

Keywords:

Brazilian Atlantic Forest Conservation genetics

Microsatellite markers

Population genetics

Tropical tree species

Historic:

Received 23/07/2018

Accepted 08/12/20 I 8

Correspondence: anete@unicamp.br
Patrícia M. Francisco ${ }^{\mathrm{la}}$, Evandro V. Tambarussi ${ }^{2}$, Fábio de M. Alves ${ }^{\mathrm{lb}}$, Stephanie Bajay ${ }^{\mathrm{lc}}$, Maisa Ciampi-Guillardi ${ }^{1 \mathrm{~d}, 3}$, Anete P. Souza ${ }^{\mathrm{le}+}$

\title{
GENETIC DIVERSITY AND MATING SYSTEM OF Rhizophora mangle L. (RHIZOPHORACEAE) IN NORTHERN BRAZIL REVEALED BY MICROSATELLITE ANALYSIS
}

FRANCISCO, P. M. TAMBARUSSI, E. V. ALVES, F. M. BAJAY, S. CIAMPI-GUILLARDI, M. SOUZA, A. P. Genetic diversity and mating system of Rhizophora mangle L. (Rhizophoraceae) in Northern Brazil revealed by microsatellite analysis. CERNE, v. 24, n. 4, p. 295-302, 2018.

\section{HIGHLIGHTS}

Rhizophora mangle has low occurrence of self-pollination and low occurrence of mating among relatives.

One to 12 pollen donors fertilized each seed tree. However, Genetic diversity was low.

The number of seed trees required for seed collection $(\hat{m})$ was 62 and ranged from 40 to 107.

This study provides ecological and management implications for R. mangle.

\section{ABSTRACT}

Rhizophora mangle L. (Rhizophoraceae) grows on aerial roots, which emerge above the water level, giving stands of this tree the characteristic "mangrove" appearance. To produce in situ and ex situ information for genetic conservation programs for this species, we investigated the genetic diversity and mating system of one $R$. mangle population. We sampled 30 adult trees and a total of 349 seeds in Northern Brazil. We genotyped all adult trees and seeds with four microsatellite loci. The average fixation index was -0.222 for adult trees and 0.030 for seeds. The multilocus outcrossing rate $\left(t_{m}=0.921\right)$ was significantly lower than unity $(I .0)$. There was no substantial evidence of null alleles nor genotypic disequilibrium among the loci. The combined power to exclude the first parent probability was 0.921 . The average coancestry coefficient $(\bar{\theta}:=0.180)$ was similar to that expected for half-sib progenies $(\bar{\theta}:=0.125)$. Thus, the number of adult trees necessary for seed collection to obtain progeny arrays with an effective size of I 50 was estimated to be 62. In conclusion, this study produced important information for the management and conservation of $R$. mangle and will contribute to conservation and management programs for this species.

' University of Campinas, Campinas, São Paulo, Brazil - ORCID: 0000-000 I-688 I-2679a, 0000-0002-7902-49 I 5 b,

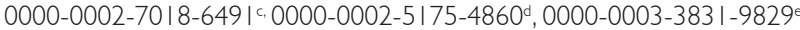




\section{INTRODUCTION}

The Rhizophora genus dominates many tropical mangrove forests worldwide and plays pivotal roles in mangrove ecosystems (Duke \& Allen, 2006). Mangroves, which are heterogeneous habitats with an uncommon variety of animals and plants adapted to conditions of high salinity, frequent flooding and muddy anaerobic soil, cover approximately I37,700 km² worldwide (Giri et al., 20 I I).

These mangrove trees have morphological characteristics and adaptations, including aerial roots and a fast-growing canopy, that contribute to efficient nutrient retention mechanisms, water retention and balance sheet carbon estimates (Ezcurra et al., 2016). Rhizophora species are mainly pollinated by the wind, as they have considerably more pollen grains than ovaries per flower (Tomlinson, 1986). The viviparous propagules of these species are dispersed by water, and their dispersion occurs under the influence of ocean currents (Francisco et al., 20l8).

Rhizophora mangle L. is a key woody plant of the Rhizophoraceae mangrove family. Widely distributed throughout the Atlantic East-Pacific biogeographic (AEP) region (Tomlinson, 1986; Takayama et al., 20I3), R. mangle was present in the Neotropical region 40 million years ago (Graham, 2006). In addition, $R$. mangle is one of the main representative species of this ecosystem in Brazil.

Although important ecosystems, mangroves are being devastated by anthropic actions. In this context, it is urgent to produce data that can help in the conservation of species that are part of mangrove habitats. The development of molecular techniques has generated opportunities to drive research on mangroves in new directions and increase knowledge on the subject of mangrove ecosystems (Triest, 2008). R. mangle plants along the eastern coast of South America demonstrate a strong genetic structure due to the influence of oceanic currents, which act both as a barrier to and a facilitator of gene flow depending on the population location (Francisco et al., 20l8; Pil et al., 20I I; Takayama et al., 20I3). The $R$. mangle genetic structure consists of an admixture gradient between two gene pools within the northern coast, whereas populations from the southern coast are homogeneous with a low genetic diversity (Francisco et al., 20l8; Pil et al., 20I I).

The species is pollinated by anemophily (wind) and by entomophily (insects) (De Menezes et al., 1997). Pollinated $R$. mangle flowers mature in approximately 95 days, producing buoyant hypocotyls also known as propagules (Alongi, 20I5). R. mangle is a living species with propagules that germinate and mature on the maternal tree before dropping off. These propagules are large and curved and are dispersed by water fluctuations until they settle, if they find an environment with adequate conditions (McKee \& Rooth, 2008). The effective genetic conservation of a species requires knowledge about its mating system and genetic diversity. In this study, we investigated genetic patterns such as the genetic diversity of Rhizophora mangle in the equatorial coast of Brazil using microsatellite markers.

\section{MATERIALS AND METHODS}

\section{Study Area, Sampling and Genotyping}

One population from the northern coast of Brazil in the municipality of Salinópolis, Pará State ( $47^{\circ} 22^{\prime} 25^{\prime \prime}$ $\mathrm{W}, 00^{\circ} 36^{\prime}$ ' $\left.8^{\prime \prime} \mathrm{S}\right)$, was chosen to study the mating system of R. mangle (Figure I).

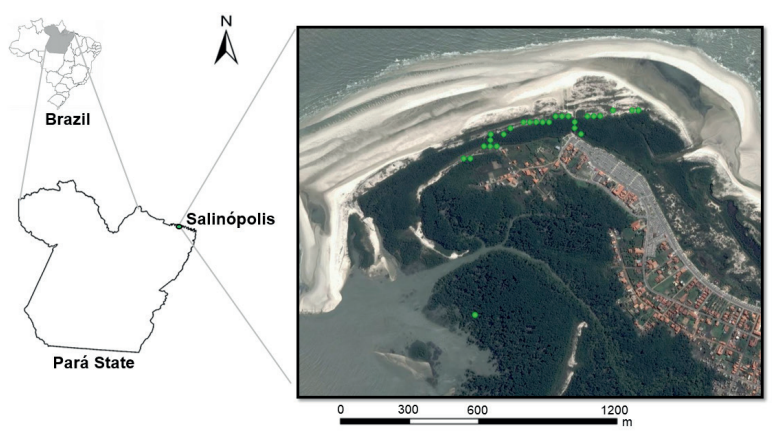

FIGURE I Locations of the Rhizophora mangle population from the northern coast of Brazil in the municipality of Salinópolis, Pará State. The spatial distribution of the collected genotypes is indicated by green dots.

Leaves were collected from 30 adult trees, and 10 to 12 seeds were collected from each adult tree ( $n=349$ ), with a minimum distance of $10 \mathrm{~m}$ between each adult tree. The geographic coordinates of each adult tree were collected using a GPS receiver (Garmin 76CSx, WGS-84 standard, Garmin International Inc., Olathe, KS, USA). DNA extractions were performed using the DNeasy ${ }^{\circledR}$ Plant Mini Kit (Qiagen, Hilden, DE, Germany). We used four microsatellites loci (Rma3-I4, Rma3-23, Rma3-37 and Rma3-38) developed by Francisco et al. (2018), and the procedures for DNA amplification and allele scoring were based on Francisco et al. (20l8).

Analysis of Genetic Diversity, Inbreeding, Relatedness and Effective Population Size

To assess the genetic diversity of adults and progenies, genetic diversity was characterized per locus and as an average across all loci using the following 
indices: average number of alleles per locus $(k)$, observed heterozygosity $\left(\mathrm{H}_{0}\right)$, and expected heterozygosity in HardyWeinberg equilibrium $\left(H_{\mathrm{e}}\right)$. To check whether there was inbreeding in the adults (seed trees) and progeny, we used the within-population fixation index $\left(F_{15}\right) ; 1,000$ bootstrap replicates were used to calculate the $95 \%$ confidence interval limits for the fixation index. The statistical significance of was tested by permuting alleles among individuals. All analyses were performed using the $\mathrm{R}$ ( $\mathrm{R}$ Development Core Team, 20I5) package diveRsity (Keenan et al., 20I3), and bootstrapped confidence intervals were also calculated for each $F_{\text {IS }}$ value. Linkage was estimated for adult trees using the FSTAT program (Goudet, 1995). We estimated null allele frequencies using FreeNa software (Chapuis \& Estoup, 2007). For adult trees, the power to exclude the first parent (when none of the relatives were known) ( $P I$ parent) was estimated using Cervus 3.0.3 (Marshall et al., 1998).

The average coancestry coefficient within ) and among $\left(\bar{\theta}_{a}\right)$ of all progeny arrays was estimated by the maximum-likelihood estimator, and I,000 bootstrap replicates were used to calculate the $95 \%$ confidence intervals for the coancestry index in Software Coancestry (Wang, 20II). The effective population sizes within and among for the progeny arrays were estimated following Sebbenn (2006).

\section{Mating System Analysis}

Mating system analyses were performed with the multilocus analysis program MLTR v.3.4 (Ritland, 2002). This analysis considers the reproduction system based on a mixed model (Ritland \& Jain, 198I). The MS (maximization expectation) numerical method was adopted for the families in the analysis with a $95 \%$ confidence interval $(\mathrm{Cl})$ and 10,000 bootstrap resampling. The multilocus outcrossing rate $\left(t_{m}\right)$, single-locus outcrossing rate $\left(t_{s}\right)$, crossing between related species $\left(t_{m}-t_{s}\right)$, multilocus correlation inbreeding $\left(r_{s}\right)$, and multilocus correlation pollen $\left(r_{(p m)}\right)$ were estimated for the whole population and each adult tree. Mating system indices were used to estimate other indices as follows. The effective number of pollen donors was calculated by $\mathrm{Nep}=\mathrm{I} / \mathrm{rp}$. The number of adult trees required for seed collection to yield a progeny array with an effective size of I 50 was estimated with the equation $\hat{m}=N_{\text {e(reference })} / \hat{N}_{e(v)}$ (Sebbenn, 2006).

\section{RESULTS}

Genetic diversity, inbreeding, relatedness and effective population size

When we evaluated the genetic diversity and inbreeding of the total sample, we found 10 alleles in the adult trees and 12 alleles in the seeds, with two private alleles within the seed arrays (Table I). The size of the private alleles was 242 (frequency of 0.722) for locus RM7576 and 200 (frequency of 0.003) for locus RM4546.

The observed heterozygosity $\left(H_{o}\right)$ was similar for adult trees and seeds only for locus RM7576; however, the expected heterozygosity $\left(H_{e}\right)$ was similar for all loci, and the average heterozygosity significantly departed from Hardy-Weinberg equilibrium.

Several authors around the world have studied $R$. mangle. Thus, a wide range of research focusing on hybridization and genetic diversity is available in the literature. However, mating system research for this species is still scarce. These authors have used up to I5 markers (ranging from 3 to 15) to obtain similar estimates. For this species, the number of alleles appears to range from I to 10. The measures of observed heterozygosity are very similar (ranging from zero to 0.80 ) among studies published from 2007 until today (Table 2). Therefore, the markers used in this research show robustness in the analyses and can be used for reliable estimates.

TABLE I Genetic diversity and fixation index (F) parameters for four microsatellite loci in adults and progeny of the Rhizophora mangle population from the northern coast of Brazil in the municipality of Salinópolis, Pará State.

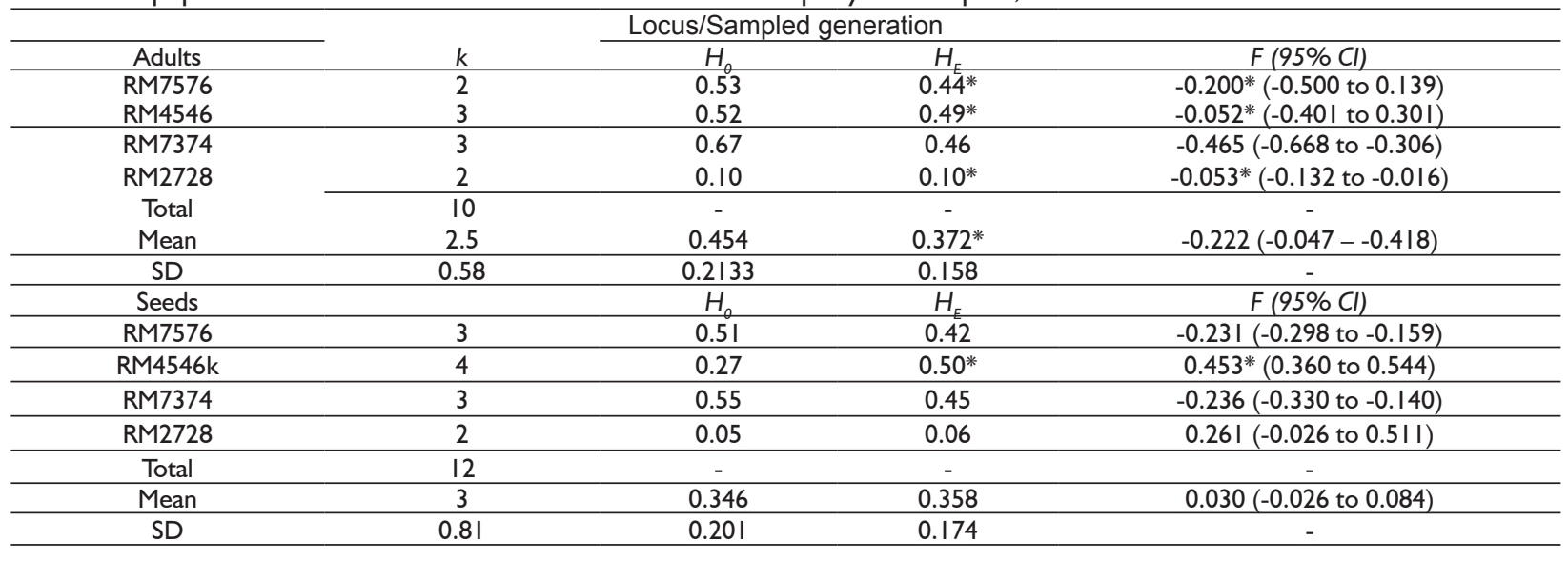

*Significant departures from Hardy-Weinberg equilibrium at $\mathrm{P}<0.05 ; 95 \% \mathrm{Cl}$ indicates the $95 \%$ confidence interval. 
TABLE 2 Range of observed heterozygosity (Ho) in populations of Rhizophora mangle.

\begin{tabular}{cccc}
\hline Authors & Number of SSRs & Range of number of alleles/locus & $\begin{array}{c}\text { Range of observed heterozygosity } \\
(\text { Ho) }\end{array}$ \\
\hline Rosero-Galindo et al. (2002) & 10 & $2-7$ & $0.20-0.80$ \\
Arbeláez-Cortes et al. (2007) & 3 & $3-6$ & $0.34-0.60$ \\
Pil et al. (20II)* & 8 & NS & $0.01-0.26$ \\
Ribeiro et al. (2013) & 7 & $3-10$ & $0.04-0.64$ \\
São Paulo population & & $3-11$ & $0.17-0.75$ \\
Bragança population & & $1-10$ & $0-0.52$ \\
Florida population & 7 & NS & $0.20-0.48$ \\
Kennedy et al. (2016)* & 5 & $2-5$ & $0.189-0.405$ \\
Basyuni et al. (2017) & 15 & NS & $0-0.65$ \\
Francisco et al. (2018)* & 4 & $2-4$ & $0-0.67$ \\
Present study & & & \\
\hline
\end{tabular}

*mean for each population, NS: alleles per locus not shown

In terms of the average, the fixation index presented a higher level of heterozygosity for adult trees than for seeds (Table I; Figure 2). The average fixation index $\left(F_{S}\right)$ had higher values in seeds, with an overall value of 0.03 (ranging from -0.026 to 0.084 ), than in adult trees, with an overall value of -0.222 (ranging from -0.047 to -0.418 ) (Figure 2). Thus, these results indicate the occurrence of endogamy in seeds after reproductive event.

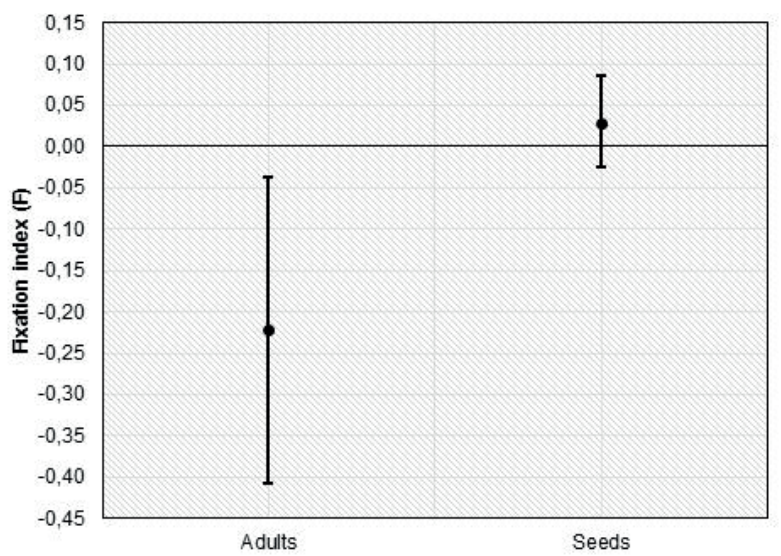

FIGURE 2 Intrapopulation fixation index (FIS) parameters estimated with four microsatellite loci in adult trees and progeny arrays (seeds) of the Rhizophora mangle population from the northern coast of Brazil in the municipality of Salinópolis, Pará State.

The FreeNa software analysis revealed null alleles at one locus (RM4546) (Table 3).

No linkage disequilibrium was detected in the studied populations for an adjusted P-value at the 5\% nominal level (data not shown). All loci were appropriate for genetic population studies on $R$. mangle. The average power to exclude the first parent $(P I$ parent) was $0.92 \mathrm{I}$, and this value indicates that these loci are suitable for future parentage studies.

\section{Mating System}

The multilocus outcrossing rate $\left(t_{m}\right)$ was not significantly different from unity (I.0), indicating a low occurrence of self-pollination (Table 3). However, the single-locus outcrossing rate $\left(t_{s}\right)$ was significantly lower than unity (I.0) and significantly lower than the multilocus outcrossing rate, resulting in a nonsignificant difference in $t_{m}-t_{s}$. This result suggests the low occurrence of mating among relatives. The multilocus paternity correlation for the population $\left(r_{p(m)}\right)$ was significantly greater than zero, indicating correlated mating (Table 4). However, the multilocus paternity

TABLE 3 Null allele estimates for four microsatellite loci in progeny arrays (seeds) of the Rhizophora mangle population from the northern coast of Brazil in the municipality of Salinópolis, Pará State.

\begin{tabular}{|c|c|c|c|c|}
\hline \multirow{2}{*}{ Family } & \multicolumn{4}{|c|}{ Markers } \\
\hline & RM7576 & RM4546 & RM7374 & RM2728 \\
\hline $\mathrm{FI}$ & 0.000 & 0.000 & 0.000 & 0.001 \\
\hline $\mathrm{F} 2$ & 0.001 & 0.000 & 0.000 & 0.001 \\
\hline F3 & 0.000 & 0.000 & 0.000 & 0.000 \\
\hline $\mathrm{F} 4$ & 0.000 & 0.000 & 0.000 & 0.001 \\
\hline F5 & 0.000 & 0.000 & 0.000 & 0.001 \\
\hline F6 & 0.000 & 0.201 & 0.000 & 0.001 \\
\hline F7 & 0.000 & 0.167 & 0.000 & 0.001 \\
\hline F8 & 0.000 & 0.265 & 0.000 & 0.001 \\
\hline F9 & 0.000 & 0.200 & 0.000 & 0.000 \\
\hline FIO & 0.000 & 0.001 & 0.000 & 0.000 \\
\hline $\mathrm{FII}$ & 0.000 & 0.000 & 0.000 & 0.000 \\
\hline $\mathrm{FI} 2$ & 0.000 & 0.000 & 0.000 & 0.001 \\
\hline $\mathrm{FI3}$ & 0.000 & 0.000 & 0.000 & 0.001 \\
\hline $\mathrm{FI} 4$ & 0.000 & 0.008 & 0.000 & 0.001 \\
\hline FI5 & 0.000 & 0.000 & 0.000 & 0.001 \\
\hline FI6 & 0.000 & 0.000 & 0.000 & 0.001 \\
\hline FI7 & 0.000 & 0.000 & 0.000 & 0.001 \\
\hline FI8 & 0.000 & 0.000 & 0.000 & 0.001 \\
\hline FI9 & 0.000 & 0.001 & 0.000 & 0.001 \\
\hline $\mathrm{F} 20$ & 0.000 & 0.000 & 0.000 & 0.001 \\
\hline F2I & 0.000 & 0.000 & 0.000 & 0.001 \\
\hline $\mathrm{F} 22$ & 0.000 & 0.001 & 0.024 & 0.001 \\
\hline F23 & 0.000 & 0.000 & 0.000 & 0.024 \\
\hline $\mathrm{F} 24$ & 0.000 & 0.188 & 0.000 & 0.001 \\
\hline $\mathrm{F} 25$ & 0.000 & 0.001 & 0.000 & 0.001 \\
\hline F26 & 0.000 & 0.167 & 0.000 & 0.001 \\
\hline $\mathrm{F} 27$ & 0.000 & 0.001 & 0.000 & 0.001 \\
\hline F28 & 0.001 & 0.000 & 0.000 & 0.001 \\
\hline F29 & 0.000 & 0.00 & 0.000 & 0.001 \\
\hline $\mathrm{F} 30$ & 0.000 & 0.000 & 0.000 & 0.001 \\
\hline
\end{tabular}

Notes: Bold values present evidence of a null allele, assuming a null frequency $<0.20$. 
correlation was significantly lower among families (Table 5). Consequently, the effective number of pollen donors was significantly lower within progenies, which indicates that between one and thirteen pollen donors fertilized each adult tree. The selfing correlation $\left(r_{s}\right)$ was significantly different from zero, demonstrating variation in the outcrossing rate.

TABLE 4 Mating system parameters for Rhizophora mangle populations $(95 \% \mathrm{Cl}$ indicates the $95 \%$ confidence interval) from the northern coast of Brazil in the municipality of Salinópolis, Pará State.

\begin{tabular}{cc}
\hline Parameter & Estimates $(95 \% \mathrm{Cl})$ \\
\hline Number of adult trees (number of progenies) & $30(349)$ \\
Multilocus outcrossing rate: & 0.92 I $(0.9$ I I to 0.930$)$ \\
Single-locus outcrossing rate: & $0.846(0.805$ to 0.886$)$ \\
Mating among relatives: & $0.075(0.046$ to 0.106$)$ \\
Selfing correlation: & $0.166(0.166$ to 0.266$)$ \\
Multilocus paternity correlation: & $0.624(0.493$ to 0.655$)$ \\
Effective number of pollen donors: & $\mathrm{I} .6(\mathrm{I} .5$ to 2.0$)$ \\
Number of adult trees: $\mathrm{m}$ & $62(40$ to I07)
\end{tabular}

At the progeny level, the multilocus paternity correlation ( $\left.r_{p(m)}\right)$ ranged from 0.080 to 0.712 , indicating correlated mating (Table 4). Consequently, the effective number of pollen donors presented wide variation among progenies $\left(N_{e p}\right)$, which indicated that from one to 12 pollen donors fertilized each adult tree.The average coancestry coefficient among progenies $\left(\bar{\theta}_{a}\right)$ was 0.180 , and the variance effective size $\left(N_{\mathrm{e}(a)}\right)$ was 2.4l. The number of adult trees required for seed collection $(\hat{m})$ was 62 and ranged from 40 to 107 . The average coancestry coefficient within progenies $\left(\bar{\theta}_{w}\right)$ ranged among adult trees from 0.105 to 0.353 , and the variance in effective population size among adult trees $\left(N_{e(w)}\right)$ ranged from I.4 to 3.7 (Table 4).

\section{DISCUSSION}

Genetic diversity was low for this studied population of $R$. mangle. With the set of $R$. mangle primer pairs that were used in this study, we found a total of 12 alleles. However, no inbreeding was detected using

TABLE 5 Mating system ( $\pm S D$, standard deviation) indices for open-pollinated progeny arrays from the Rhizophora mangle population from the northern coast of Brazil in the municipality of Salinópolis, Pará State.

\begin{tabular}{|c|c|c|c|c|c|c|c|c|c|}
\hline Progeny & $n$ & $t_{m}$ & $t_{s}$ & $t_{m}-t_{s}$ & $r_{s}$ & $r_{p(m)}$ & $N_{\mathrm{ep}}$ & $\bar{\theta}_{w}$ & $N_{\mathrm{e}(w)}$ \\
\hline $\mathrm{FI}$ & 12 & $0.986 \pm 0.011$ & $0.945 \pm 0.015$ & $0.041 \pm 0.005$ & $0.100 \pm 0.005$ & $0.139 \pm 0.016$ & 7.2 & 0.153 & 2.8 \\
\hline $\mathrm{F} 2$ & 12 & $0.922 \pm 0.020$ & $0.902 \pm 0.006$ & $0.020 \pm 0.014$ & $0.115 \pm 0.008$ & $0.179 \pm 0.048$ & 5.6 & 0.131 & 3.1 \\
\hline F3 & 10 & $0.981 \pm 0.014$ & $0.952 \pm 0.016$ & $0.029 \pm 0.005$ & $0.182 \pm 0.032$ & $0.285 \pm 0.045$ & 3.5 & 0.112 & 3.4 \\
\hline $\mathrm{F} 4$ & 12 & $0.849 \pm 0.031$ & $0.870 \pm 0.018$ & $-0.021 \pm 0.016$ & $0.105 \pm 0.004$ & $0.120 \pm 0.017$ & 8.3 & 0.211 & 2.1 \\
\hline F5 & II & $0.928 \pm 0.019$ & $0.913 \pm 0.009$ & $0.015 \pm 0.010$ & $0.108 \pm 0.006$ & $0.111 \pm 0.016$ & 9.0 & 0.117 & 3.4 \\
\hline F6 & 12 & $0.982 \pm 0.014$ & $0.943 \pm 0.016$ & $0.039 \pm 0.005$ & $0.106 \pm 0.005$ & $0.115 \pm 0.015$ & 8.7 & 0.157 & 2.7 \\
\hline F7 & 12 & $0.981 \pm 0.013$ & $0.940 \pm 0.014$ & $0.041 \pm 0.004$ & $0.1 I I \pm 0.006$ & $0.104 \pm 0.016$ & 9.6 & 0.105 & 3.7 \\
\hline F8 & II & $0.934 \pm 0.016$ & $0.910 \pm 0.007$ & $0.024 \pm 0.010$ & $0.106 \pm 0.004$ & $0.124 \pm 0.015$ & 8.0 & 0.127 & 3.1 \\
\hline F9 & 12 & $0.964 \pm 0.016$ & $0.931 \pm 0.012$ & $0.033 \pm 0.005$ & $0.120 \pm 0.007$ & $0.154 \pm 0.015$ & 6.5 & 0.110 & 3.6 \\
\hline FIO & 12 & $0.975 \pm 0.015$ & $0.899 \pm 0.010$ & $0.076 \pm 0.016$ & $0.160 \pm 0.027$ & $0.345 \pm 0.084$ & 2.9 & 0.141 & 3.0 \\
\hline $\mathrm{FII}$ & 12 & $0.970 \pm 0.016$ & $0.929 \pm 0.012$ & $0.04 I \pm 0.006$ & $0.109 \pm 0.005$ & $0.142 \pm 0.026$ & 7.0 & 0.280 & 1.7 \\
\hline $\mathrm{FI} 2$ & II & $0.942 \pm 0.018$ & $0.915 \pm 0.009$ & $0.027 \pm 0.010$ & $0.125 \pm 0.016$ & $0.237 \pm 0.085$ & 4.2 & 0.152 & 2.8 \\
\hline $\mathrm{FI3}$ & 12 & $0.924 \pm 0.023$ & $0.907 \pm 0.009$ & $0.017 \pm 0.014$ & $0.127 \pm 0.015$ & $0.236 \pm 0.084$ & 4.2 & 0.133 & 3.0 \\
\hline $\mathrm{FI} 4$ & 12 & $0.906 \pm 0.029$ & $0.900 \pm 0.007$ & $0.006 \pm 0.022$ & $0.128 \pm 0.015$ & $0.243 \pm 0.082$ & 4.1 & 0.150 & 2.8 \\
\hline FI5 & 12 & $0.967 \pm 0.016$ & $0.933 \pm 0.013$ & $0.034 \pm 0.004$ & $0.104 \pm 0.004$ & $0.098 \pm 0.011$ & 10.2 & 0.133 & 3.1 \\
\hline FI6 & 12 & $0.662 \pm 0.032$ & $0.734 \pm 0.074$ & $-0.072 \pm 0.046$ & $0.107 \pm 0.002$ & $0.101 \pm 0.006$ & 9.9 & 0.168 & 2.6 \\
\hline $\mathrm{FI7}$ & 12 & $0.831 \pm 0.046$ & $0.890 \pm 0.009$ & $-0.059 \pm 0.009$ & $0.095 \pm 0.003$ & $0.078 \pm 0.010$ & 12.8 & 0.236 & 2.0 \\
\hline FI8 & 12 & $0.860 \pm 0.029$ & $0.837 \pm 0.038$ & $0.023 \pm 0.025$ & $0.094 \pm 0.004$ & $0.079 \pm 0.011$ & 12.6 & 0.109 & 3.6 \\
\hline FI9 & II & $0.815 \pm 0.069$ & $0.872 \pm 0.018$ & $-0.057 \pm 0.019$ & $0.137 \pm 0.014$ & $0.304 \pm 0.019$ & 3.3 & 0.149 & 2.8 \\
\hline $\mathrm{F} 20$ & 12 & $0.930 \pm 0.012$ & $0.904 \pm 0.007$ & $0.026 \pm 0.008$ & $0.121 \pm 0.012$ & $0.207 \pm 0.067$ & 4.8 & 0.282 & 1.6 \\
\hline $\mathrm{F} 2 \mathrm{I}$ & 12 & $0.916 \pm 0.019$ & $0.905 \pm 0.006$ & $0.011 \pm 0.014$ & $0.114 \pm 0.007$ & $0.164 \pm 0.040$ & 6.1 & 0.202 & 2.2 \\
\hline $\mathrm{F} 22$ & 12 & $0.991 \pm 0.009$ & $0.760 \pm 0.048$ & $0.231 \pm 0.055$ & $0.481 \pm 0.142$ & $0.885 \pm 0.102$ & I.I & 0.155 & 2.8 \\
\hline $\mathrm{F} 23$ & 12 & $0.488 \pm 0.163$ & $0.758 \pm 0.069$ & $-0.270 \pm 0.003$ & $0.113 \pm 0.005$ & $0.120 \pm 0.003$ & 8.3 & 0.132 & 3.1 \\
\hline $\mathrm{F} 24$ & 12 & $0.724 \pm 0.128$ & $0.870 \pm 0.025$ & $-0.146 \pm 0.105$ & $0.151 \pm 0.028$ & $0.286 \pm 0.083$ & 3.5 & 0.353 & 1.4 \\
\hline $\mathrm{F} 25$ & II & $0.934 \pm 0.016$ & $0.881 \pm 0.013$ & $0.053 \pm 0.019$ & $0.124 \pm 0.012$ & $0.229 \pm 0.062$ & 4.4 & 0.191 & 2.3 \\
\hline $\mathrm{F} 26$ & II & $0.900 \pm 0.017$ & $0.893 \pm 0.007$ & $0.004 \pm 0.012$ & $0.094 \pm 0.003$ & $0.080 \pm 0.009$ & 12.5 & 0.210 & 2.1 \\
\hline $\mathrm{F} 27$ & 12 & $0.605 \pm 0.130$ & $0.805 \pm 0.058$ & $-0.197 \pm 0.076$ & $0.130 \pm 0.012$ & $0.199 \pm 0.034$ & 5.0 & 0.216 & 2.1 \\
\hline $\mathrm{F} 28$ & 12 & $0.669 \pm 0.095$ & $0.840 \pm 0.035$ & $-0.174 \pm 0.062$ & $0.108 \pm 0.002$ & $0.116 \pm 0.005$ & 8.6 & 0.274 & 1.7 \\
\hline $\mathrm{F} 29$ & II & $0.993 \pm 0.007$ & $0.950 \pm 0.016$ & $0.043 \pm 0.010$ & $0.267 \pm 0.088$ & $0.712 \pm 0.186$ & 1.4 & 0.218 & 2.0 \\
\hline $\mathrm{F} 30$ & 10 & $0.808 \pm 0.061$ & $0.885 \pm 0.010$ & $-0.077 \pm 0.05 \mid$ & $0.101 \pm 0.001$ & $0.101 \pm 0.003$ & 9.9 & 0.317 & 1.5 \\
\hline
\end{tabular}


the average fixation index $(F)$ estimate at the adult level. Inbreeding was detected in the progeny array (Figure I). The number of alleles obtained in this study was lower than that obtained by Pil et al. (20 I I) for the same species from the Brazilian coast, although those authors used a different set of loci and number of individuals across 10 populations. We observed an average heterozygosity of 0.454 and an average expected heterozygosity of 0.372 for adult trees (Table I), and these results were similar to those of other studies (Forti et al., 2014; Kennedy et al., 2017). Forti. et al. and Kennedy et al. found low outcrossing rates, suggesting that a high rate of selfing decreased the genetic diversity. Evidence of low genetic diversity has been detected by previous studies on mangrove species (Basyuni et al. 20I7; Pil et al., 20I I).

The effect of the mating system on genetic diversity has been observed in other studies on tropical tree species (Tambarussi et al., 2016). For our results, the mating system analysis presented high outcrossing rates ( $\geq 0.900$ in 20 families; Table 4) and evidence of mating between relatives only for one progeny (F22) (Table 4). Similar to our study, in Mexico, Sandoval-Castro et al. (2012) found reduced genetic diversity and increased inbreeding in $R$. mangle. Some studies investigating mating systems have found evidence of selfing for $R$. mangle (Lowenfeld \& Klekowski, 1992). However, the mating system patterns of a tree species can be controlled by the environment and genetic processes. Thus, some adult trees, populations or even reproductive events may present higher or lower percentages of self-fertilization (Tambarussi et al., 2016; Tambarussi et al., 2017). This result can be observed in the $R$. mangle population of this study, which demonstrated progeny array self-fertilization values ranging from 0.488 (for FI6) to 0.993 (F30) (Table 4 ). Due to the detected selfing, the average coancestry coefficient within progenies $(\bar{\theta}=0.180)$ and effective size variance $\left(N_{e}=2.4 \mathrm{I}\right)$ of this population were similar to those expected for panmictic populations $(\bar{\theta}=0.125$, $N_{\mathrm{e}} \approx 4$ ). Thus, the open-pollinated progenies were composed mainly of half-sibs families. These percentages may have strong implications for the collection of seeds for the conservation, restoration of degraded areas and for the preimprovement of the tree species (Tambarussi et al., 2017).

\section{CONCLUSIONS}

This study provides ecological and management implications for $R$. mangle. Despite the small number of microsatellite loci studied in this population, we found an increase in the endogamy of the studied seed generation, even with the observation of high outcrossing rates. This fact can be explained by the process of forest fragmentation. Other studies have shown similar levels of genetic diversity with only five (Basyuni et al., 2017) and seven (Kennedy and Garavelli, 2017) microsatellite loci. The four microsatellite markers in this study presented a high power of parent exclusion, moderate genetic diversity and no linkage disequilibrium. Therefore, all these analyses indicated that this set of microsatellite loci could be used without restriction in studies on the genetic diversity, genetic structure, mating system, and parentage of $R$. mangle.

\section{ACKNOWLEDGMENTS}

The authors thank I. C. Menezes, I. Sampaio, L. G. Dantas de Oliveira, and M. A. Louzada for their sampling support and assistance in the field and $\mathrm{P}$. Zambon, A. Moares and D. A. Sforça for their support in the laboratory. The authors gratefully acknowledge the Fundação de Amparo a Pesquisa do Estado de São Paulo(FAPESP, 2008/52045-0 and 2010/50I 78-2) and the Coordenação de Aperfeiçoamento de Pessoal de Nível Superior (CAPES - Computational Biology Program, project number 88882.160095/20I3OI for financial support, scholarships from FAPESP to PMF (DD 2008/56404-4), and the Conselho Nacional de Desenvolvimento Científico e Tecnológico (CNPq) for a research fellowship to APS. The funders had no role in the study design, data collection and analysis, decision to publish, or manuscript preparation.

\section{REFERENCES}

ALONGI, D.M. The impact of climate change on mangrove forests. Current Climate Change Reports, v. I, n. I, p.30$39,2015$.

ARBELÁEZ-CORTES, E.; CASTILLO-CÁRDENAS, M.F.; TORO-PEREA, N.; CÁRDENAS-HENAO, H. Genetic structure of the red mangrove (Rhizophora mangle L.) on the Colombian Pacific detected by microsatellite molecular markers. Hydrobiologia, v.583, n. I, p.32I-330, 2007.

BASYUNI, M.; BABA, S.; OKU, H.Microsatellite analysis on genetic variation in two populations of red mangrove Rhizophora mangle L. (Rhizophoraceae) and its implication to conservation. IOP Conference Series: Materials Science and Engineering, v. I80, n. I,2017.

CHAPUIS, M.P.; ESTOUP, A. Microsatellite null alleles and estimation of population differentiation. Molecular Biology and Evolution, v.24, n.3, p.62 I-63I, 2007

MENEZES, M.P.M.; OLIVEIRA, D.; MELLO, C.F. Pollination of red mangrove, Rhizophora mangle, in northern Brazil. Acta Horticulturae, v.437, n.437, p. 43 I-434, 1997. 
DUKE, N. C.; ALLEN, J. A. Rhizophora mangle, R. samoensis, R. racemosa, $R$. $\times$ Harrisonii (Atlantic-east Pacific red mangrove), In Elevitch C.R., Abbott I.A., Leakey R. R. B. (ed.) Species profiles for pacific island agroforestry. Honolulu, HI: Permanent Agriculture Resources, pp. 623-640, 2006

EZCURRA, P.; EZCURRA, E.; GARCILLÁN, P.P.; COSTA, M.T.; ABURTO-OROPEZA, O. Coastal landforms and accumulation of mangrove peat increase carbon sequestration and storage. Proceedings of the National Academy of Sciences of the United States of America, v. II3, n.16, p. 4404-4409, 2016

FORTI, G.; TAMBARUSSI, E.V.; KAGEYAMA, P.Y.; MORENO, M.A.; FERRAZ, E.M.; IBAÑES, B.; VENCOVSKY, R.; MORI, G.M.; SEBBENN, A.M. Low genetic diversity and intrapopulation spatial genetic structure of the Atlantic Forest tree, Esenbeckia leiocarpa Engl. (Rutaceae). Annals of Forest Research, v.57, n.2, p. $165-174,2014$

FRANCISCO, P.M.; MORI, G.M.; ALVES, F.M.; TAMBARUSSI, E.V., SOUZA, A.P. Population genetic structure, introgression, and hybridization in the genus Rhizophora along the Brazilian coast. Ecology and Evolution v.8, n.6, p.349I-3504, 2018

GIRI C., OCHIENG E., TIESZEN L.L., ZHU Z., SINGH A., LOVELAND T., MASEK J., DUKE N.Status and distribution of mangrove forests of the world using earth observation satellite data. Global Ecology and Biogeography, v.20, n. I, p.I54-159, 201 I

GOUDET, J. FSTAT (Version I.2): A computer program to calculate F-statistics. Journal of Heredity, I.2 version v.86, n.6, p. 485-486, 1995.

GRAHAM, A. Paleobotanical evidence and molecular data in reconstructing the historical phytogeography of Rhizophoraceae I. Annals of the Missouri Botanical Garden, v.93, n.2, p.325-334, 2006

KEENAN, K.; MCGINNITY, P.; CROSS, T.F.; CROZIER, W.W.; PRODÖHL, P.A. DiveRsity: an R package for the estimation and exploration of population genetics parameters and their associated errors. Methods in Ecology and Evolution v.4, n.8, p.782-788, 2013.

KENNEDY, J.P.; GARAVELLI, L.; TRUELOVE, N.K.; DEVLIN, D.J.; BOX, S.J.; CHÉRUBIN, L.M.; FELLER, I.C. Contrasting genetic effects of red mangrove (Rhizophora mangle L.) range expansion along West and East Florida. Journal of Biogeography, v.44, n.2, p.335-347, 2017.

LOWENFELD, R.; KLEKOWSKI, E.J. Mangrove genetics. I. Mating system and mutation rates of Rhizophora mangle in Florida and San Salvador Island, Bahamas. International Journal of Plant Sciences I53(v.3, n.Part I): 394-399, 1992

MARSHALL, T.C.; SLATE, J.; KRUUK, L.E.B.; PEMBERTON J.M. Statistical confidence for likelihood-based paternity inference in natural populations. Molecular Ecology, v.7, n.5, p.639-655, 1998.
MCKEE, K.L.; ROOTH, J.E. Where temperate meets tropical: multi-factorial effects of elevated $\mathrm{CO} 2$, nitrogen enrichment, and competition on a mangrove-salt marsh community. Global Change Biology, v. I4, n.5, p.97|-984, 2008.

Pil M.W., Boeger M.R., Muschner V.C., Pie M.R., Ostrensky A., Boeger W.A., 20II. Postglacial north-south expansion of populations of Rhizophora mangle (Rhizophoraceae) along the Brazilian coast revealed by microsatellite analysis. American Journal of Botany, v.98, n.6, p. I03I-I039.

$R$ DEVELOPMENT CORE TEAM 20I5. A language and environment for statistical computing. R Foundation for Statistical Computing, Vienna, Austria. <https://www.Rproject.org $>/$. (accessed: 07 abril 2018).

RIBEIRO, D.O.; VINSON, C.C.; NASCIMENTO, D.S.S.; MEHLIG, U.; MENEZES, M.P.; SAMPAIO, I.; SILVA M.B. Isolation of microsatellite markers for the red mangrove, Rhizophora mangle (Rhizophoraceae). Applications in Plant Sciences, v. I, n.9, p.25202582, 2013.

RITLAND, K. Extensions of models for the estimation of mating systems using $n$ independent loci. Heredity, v. 88 , n.4, p. $221-228,2002$

RITLAND, K.; JAIN, S. A model for the estimation of outcrossing rate and gene frequencies using $\mathrm{n}$ independent loci. Heredity, v.47, n. I, p. 35-52, I 981.

ROSERO-GALINDO, C.; GAITAN-SOLIS, E.; CÁRDENASHENAO, H.; TOHME, J.; TORO-PEREA, N. Polymorphic microsatellites in a mangrove species, Rhizophora mangle $\mathrm{L}$. (Rhizophoraceae). Molecular Ecology Notes, v.2, n.3, p. 28I-283, 2002.

SANDOVAL-CASTRO, E.; MUÑIZ-SALAZAR, R.; ENRÍOUEZPAREDES, L.M.; RIOSMENA-RODRÍGUEZ, R.; DODD, R.S.; TÓVILLÄ-HERNÁNDEZ, C.; ARREDONDOGARCÍA, M.C. Genetic population structure of red mangrove (Rhizophora mangle L.) along the northwestern coast of Mexico. Aquatic Botany 99: 20-26, 2012.

SEBBENN, A.M. Sistema de Reprodução em espécies arbóreas tropicais e suas implicações para a seleção de árvores matrizes para reflorestamento ambientais. In Silva L.D., Higa A.R. (ed.) Pomar de sementes de espécies florestais nativas. FUPEF, Curitiba, pp. 93-I38, 2006.

TAKAYAMA, K.; TAMURA, M.; TATEISHI, Y.; WEBB,E.L.;KAIITA, T. Strong genetic structure over the American continents and transoceanic dispersal in the mangrove genus Rhizophora (Rhizophoraceae) revealed by broad-scale nuclear and chloroplast DNA analysis. American Journal of Botany, v.100, n.6, p.II9I-I20I, 2013.

TAMBARUSSI, E.V.; BOSHIER, D.H.; VENCOVSKY, R.; FREITAS, M.L.M.; DI-DIO, O.J.; SEBBENN A.M. Several small: how inbreeding affects conservation of Cariniana legalis Mart. Kuntze (Lecythidaceae) the Brazilian Atlantic Forest's largest tree. International Forestry Review, v. 18, n.4, p.502-510, 2016.

TAMBARUSSI, E.V.; SEBBENN, A.M.; ALVES-PEREIRA, A.; VENCOVSKY, R.; CAMBUIM, J.; DA SILVA, A.; MORAES, M.; DE MORAES, M.L.T. Dipteryx alata Vogel (Fabaceae) a Neotropical tree with high level of selfing: implication for conservation and breeding programs. Annals of Forest Research, v.60, n.2, p.243-26I, 2017.

TOMLINSON, P. B. The botany of mangroves. Cambridge University Press, Cambridge, NY, 1986. 
TRIEST, L. Molecular ecology and biogeography of mangrove trees towards conceptual insights on gene flow and barriers: a review. Aquatic Botany, v.89, n.2, p.|38-I54, 2008.
WANG, J. Coancestry: a program for simulating, estimating and analysing relatedness and inbreeding coefficients. Molecular Ecology Resources, v. I I, n. I, p. I4I-I45, 20 I I. 